\title{
Negotiating Creativity on a Small Budget
}

\author{
Creative Assumptions in DR3's TV Commissioning
}

\author{
Mads Møller Andersen
}

\begin{abstract}
This article presents findings from a production analysis of the Danish public-service television channel DR3's fiction production Anton 90, which was made in cooperation with a small independent production company called New Creations. In the context of intensified competition on the Danish market for fiction series, the ambivalent cooperation behind this production exemplifies the low-budget efforts of a traditional public service institution to produce the fiction series that their younger target audience desires. The article uses a narrative-discursive approach to creativity and develops the term creative assumptions in order to analyse how media professionals' implicit assumptions about conditions for creativity can influence the production process, and can generate disagreements. The analysis shows that the value of Anton 90 as a product is negotiated socially by the involved parties who have quite different assumptions about how production conditions can promote creativity, and suggests that a low-budget production can still be labelled as "successful".
\end{abstract}

Keywords: television, DR, cultural production, social constructivism, media industries

\section{Introduction}

A recent study from the Danish public service media institution Danmarks Radio (DR) shows that Danes in the age group 15-29 reduced their consumption of flow television by 25 per cent in 2016 (Knudsen \& Birk 2016: 8). When measuring the time spent by this young demographic, the two biggest television channels would actually be Netflix and YouTube and not DR's channels. According to the young Danish viewers in this study, fiction is their favourite content and the reason for their preference for foreign streaming services is the large selection of fiction series (cf. Heiselberg \& Høy Svenningsen 2016). Netflix also announced recently that they have strengthened their efforts on the European market and invested $\$ 1.75$ billion in 90 different European productions (Meza 2017).

The small Danish market for fiction series is now a very competitive landscape where global streaming services with large content portfolios are trying to gain a larger market share, which puts pressure on DR's original programming. DR's channel DR3 is targeted towards the age group 15-39 and a reasonable assumption might be that it would focus 
on making fiction series to reclaim this target audience from its competitors. However, from the channel's launch in 2013 and until June 2017, DR3 only commissioned three relatively short fiction series. This article presents findings from a production study that focuses on the strategic considerations behind the production of DR3 and New Creations' youth fiction series Anton 90 from 2015. The overall research question for this article is: How did DR3 and New Creations' creative assumptions frame the production process?

This article's theoretical ambition is to use a narrative-discursive approach to creativity theory (Taylor 2013; Taylor \& Littleton 2012) and use theory on assumptions in organisational culture (Schein 1994) in an analysis of television industry practices. This combination constitutes an original contribution to the research field of studying creativity in television production and commissioning by analytically comparing the respective approaches used by the DR3 editors and the freelance employees working for New Creations. I thereby narrow the focus of this article to the creative assumptions used by DR3 and the freelance employees in this television youth fiction production.

Even though most of DR3's original programmes are factual productions, my motivation for choosing one of their few fiction productions has been the intensified competition for the younger Danish target audience after global streaming services such as Netflix and HBO Nordic have entered the Danish market with their substantial fiction portfolios. In this context, it seemed surprising that DR did not make extensive efforts to make additional original youth fiction for this audience. A reliable way to find out why DR3 was so passive was to conduct a production study and interview the parties involved, especially the managing editors at DR3. The findings provide insights into how meagre production conditions (e.g., small budget, short-term) influence the perceived creative value of a television production like Anton 90 and whether it is possible to make television fiction that fits the gatekeepers' (editors, critics, audiences) taste even with a short-term, low-budget production. In the following section, I will first present the case study and the methodology before I define the narrative-discursive approach to creativity, define Schein's concept of assumptions and analyse the creative assumptions in the case study.

\section{Case presentation}

The production of Anton 90 (DR3/New Creations 2015) was a public-private collaboration commissioned by DR3 in spite of the channel's small budget and made by the relatively inexperienced independent (external) production company New Creations. Anton 90 is characterised by its short webisode format (10 episodes of eight to nine minutes each), its point of view cinematography (literally looking through Anton's eyes), and its integration of digital and social media in the narrative. This series was the first independently produced fiction series that DR3 commissioned, but DR3 has cooperated with many different independent production companies during the last four years.

DR3's two other original fiction productions in the channel's portfolio had been Kødkataloget [The Meat Catalogue] (DR3/DR Ung, 2013-14) and Generation SoMe! (DR3/DR Ung, 2017-). Both these productions were satire series made by the in-house production unit DR Ung (the youth content department at DR), which primarily makes factual television content for DR3. In DR's organisation, distribution is separated from production in the sense that DR3 manages the distribution through their television 
channel, while DR Ung or an independent company manages the actual production of the DR3 programmes.

New Creations was founded by Mikael Wulff, Anders Morgenthaler and Morten E. Wulff, and it is a relatively small private production company that specialises in comedy content for television, film, print and digital. For the production of Anton 90, they hired several freelance workers, including the director and the scriptwriters who all had some previous experience with fiction production. As for the series' format/duration with 10 episodes of eight to nine minutes each, this was a new format for both DR3 and New Creations.

Anton 90 was originally commissioned as a satire/comedy production, but due to problems on set where the comedy-heavy script did not function on camera, the director made the conscious decision to alter the mood of the series in a more dramatic direction. The result was a youth drama series that did not match the DR3 editors' expectations, but they let the production finish despite no longer believing in the series' potential (Director, interview, January 2017).

The current public-service contract between DR and the Danish government does not specifically mention or demand that DR3 should produce youth fiction nor are there any formal internal DR requirements for this content area. According to the DR3 editors, the main reason for this channel's prioritisation and scarce production of youth fiction is that it is very expensive to make television fiction. That statement has been the television industry's mantra for decades (cf. Tunstall 1993: 106). Nevertheless, Anton 90 demonstrates that DR3 can make youth fiction on a small budget that can still be deemed innovative by both collaborators and critics. However, as the analysis will demonstrate, findings from this production study point to a somewhat difficult production process where New Creations' freelance employees no longer shared the same creative assumptions as DR3.

\section{Methodological remarks}

This article's methodological approach uses production analysis and examines how certain systemic production conditions (economic, political, technological, organisational) can affect the production of media texts (Caldwell 2008; Ytreberg 2000). Media production studies use methods like interviews and observations, but typically with shorter time frames than those of ethnographers and anthropologists (e.g., Georgina Born's extensive investigation of the BBC; see Born 2005). By using ethnographic methods like observations and interviews (Hammersley \& Atkinson 1995; Kvale \& Brinkmann 2015), production studies examine the production culture and its members in a sociological manner (Frandsen 2007; Mayer, Banks \& Caldwell 2009).

The primary empirical material for this article consists of five interviews with exclusive informants (Bruun 2014) that possess a crucial knowledge about the production process behind Anton 90. All of the exclusive informants interviewed for this article occupied leading positions of importance to the decision-making process and they were aware of my intention of writing a research article about their collaboration. The informants were surprisingly frank and they did not mind speaking with me for up to an hour and a half - even those whom I had not met or talked to before. This might be because some of them felt the need to try to influence my analysis or the need to ex- 
press their ambivalent feelings about having done a production that at some point was being dismissed by the broadcaster, only to achieve praise and positive reviews later on. Furthermore, the hit youth fiction series SKAM [SHAME] (NRK P3, 2015-17) was mentioned by all my informants as a natural point of reference when discussing current developments within youth fiction production and this phenomenon will be investigated elsewhere (Andersen \& Sundet 2018).

In my contextual understanding of DR's organisation, I also draw on my observations of DR Ung's idea development process, which I observed for approximately three months during my fieldwork at DR. My fieldwork helped me to comprehend DR Ung and DR3's perception of what they understood as good/bad production conditions and I saw how fiction was not a particularly strong objective for DR Ung. This knowledge was of great help to me in interviewing the different editors where I could ask specifically about production conditions and their fiction strategy. An analysis of the idea development processes and a textual analysis of DR3's television programmes will be featured in another publication and is not the goal of this production-focused article.

\section{A narrative-discursive approach to creativity}

This article's production analysis is inspired by an approach to creativity used in narrative and discursive psychology and in the work by Stephanie Taylor and Karen Littleton (Taylor \& Littleton 2012). This approach defines creativity as a social phenomenon that depends on the collective contexts of creative worlds. In this understanding, there can be "[...] multiple meanings of creativity in play, associated with different contexts and drawn on variously and sometimes inconsistently" (Taylor 2013: 180). Through these multiple meanings, workers can identify their work and/or themselves as being creative (Taylor \& Littleton 2012).

In her article from 2013, Taylor examines the many different discourses about creativity that are articulated by both her colleagues in research and her informants. Instead of pursuing creativity as a matter of isolating an inherent and divine genius (as described in, e.g., McIntyre 2012: 12ff), this narrative-discursive approach can be used to regard creativity as a relative term or even a floating signifier (Laclau \& Mouffe 2001). ${ }^{1}$ A similar approach has been used by Stuart Cunningham when he described the creative industries' discourse about creativity as a Rorschach blot that has been interpreted in numerous ways by various governments (Cunningham 2009). These discursive approaches share similarities with psychological works on creativity, most notably Mihaly Csikszentmihalyi's systems approach to creativity (Csikszentmihalyi 1988) where he highlights the importance of the contextual factors like the particular domain and field when society evaluates cultural products' degree of creativity (Csikszentmihalyi 1991). Here, I am inspired by how Eva Novrup Redvall has used Csikszentmihalyi's systems approach to analyse screenwriting practices (Redvall 2010), but the social constructionist approach that I propose here goes in a theoretical direction where Csikszentmihalyi's systems model is not the main focus point.

Hans Westmeyer is another relevant scholar that has argued for a social constructionist concept of creativity and that creativity is dependent on societal evaluations and cannot be concieved merely as an ability that a person has or as a feature of a product: "But what makes a product a creative one? An evaluation, of course!" (Westmeyer 
1998: 14). In this line of thought, the historical context and the domain-specific conventions are regarded as highly influential when gatekeepers are to assess and attach value to originality and especially when judging novices and their work (Csikszentmihalyi 1988; Taylor 2013). In this less essentialist approach, products can have some core of originality or value that subsequently becomes socially constructed as being a creative product.

This theoretical stance is also particularly appropriate when considering the unfortunate general tendency in production studies to write about creative industries and creativity without providing a clear definition of the meaning of the word "creativity". A standard definition that is often used could be that creativity requires a) originality and b) usefulness (Runco \& Jaeger 2012). But the very point of this article's use of the narrative-discursive approach is to avoid the normative judgement of what is creative and instead focus on the specific industry practices and articulations that reveal their assumptions about conditions for creativity.

A pertinent context for this approach is the research on "the cultural industries" as an area for developing future employment of great interest to policy makers and politicians whereas many of the academic debates (especially in the UK) concentrate around capitalism, creative labour, and working conditions (Banks 2007; Cunningham 2009; Hesmondhalgh 2013). Taylor and Littleton explain the emergence of the creative industries with general "shift in the requirements of capitalist industry" (Taylor \& Littleton 2012: 3). But this explanation does not effortlessly fit the case of Anton 90, since the commissioning institution in this case is a public-service broadcaster - and not a typical commercial company. However, we can argue that market conditions influence DR to some degree and that the commissioning model used by this broadcaster tries to stimulate competition and the analysis will address this perspective.

\section{An organisational approach to assumptions}

In addition to the narrative-discursive approach, the production analysis used here also builds on the functionalist work by organisational psychologist Edgar H. Schein on artefacts, values and assumptions in organisational culture. Schein's concept of culture in an organisation is that the culture consists of all the group members' common, implicit, basic assumptions (Schein 1994: 16f). He makes the point that these basic and sometimes tacit assumptions are taken for granted within a specific cultural unit to such a degree that very few variations occur where any one member stands alone with an assumption - and if he/she does, it can be an unpleasant experience (Ibid: 29). Schein's aspiration to be the therapist that exposes some of the organisation's unhealthy basic assumptions (Ibid: $35 \mathrm{ff}$ ) can make his approach, at times, appear somewhat clinical, which this article will try not to emulate. His concept of assumptions is also quite broad and therefore potentially problematic but my intention here is to use the concept as an analytical tool to emphasise some of the underlying warrants in the language and behaviour of both the editors and the freelancers.

Another pertinent text about the organisational behaviours of media professionals is Jimmy Draper's article (2014) about creative agency and the concept of discerned savvy. His article is the research contribution that in its theory and conclusion is most similar to my own general experiences when observing the commissioning process at DR 
since it is specifically about idea development in a media organisation. Draper describes discerned savvy as the knowledge that media workers acquire about the preferences of their superiors which they then use to narrow their idea development accordingly (ibid: 1126). Draper uses this concept to define the experiences he had when observing and interviewing workers at three different magazines for men. In his interviews, the informants would express a feeling of unlimited creative freedom, but also refer to how they only considered ideas that they thought would fit their superior's taste. Draper connects this ambiguous idea development process to Amanda Lotz and Timothy Havens' concept of circumscribed agency where media workers make meaningful decisions regarding media texts, but also adhere to established norms and practices in the industry (Havens \& Lotz 2016: 161ff). Draper's article does not reference definitions or theories of creativity, but is instead framed as a critical study in the context of media industry studies and newsroom studies. By discussing the articulations of his informants as practices that maintain the hegemony of particular textual forms, Draper sounds like he is drawing on the tradition of discourse analysis (Laclau \& Mouffe 2001) in his work. These perspectives from Draper will be useful in the later discussion of discourses about creativity and commissioning.

In order to draw a parallel between the organisational and the aforementioned narrative-discursive approaches, they have both described the organisational assumptions about creativity and the tensions surrounding the notion of creative agency in an organisation. While Schein's approach adopts a functionalist and pragmatic stance towards making the organisational members aware of their own basic assumptions, Taylor and Littleton's book has a debunking effort that delves into the narratives of creative workers instead of normatively searching for creativity. In the analysis, I will combine these theoretical conceptions and apply my term creative assumptions as an analytical tool. With this term, I focus on the assumptions that the television employees have about good/bad production conditions: What do they assume promotes or prevents the creation of a successful and creative product? By combining these theoretical perspectives in the analysis, the specific assumptions about creative conditions will be analysed in an organisational context and give new insights for media production studies.

\section{DR3's creative assumptions: May the best idea win}

DR3 is organised as a channel that delegates the production to others by using the producer's choice principle where the producers ${ }^{2}$ have the freedom to choose between in-house or independent (external) suppliers in order to drive down costs (Harris 1998; Søndergaard 2003: 8). Inspired by its effect and organisational change within the BBC, this principle was installed by DR back in 1995 and from 2003, it was even a politically defined requirement along with the principle of desktop-organising the programming schedule by selecting individual programmes à la carte through the use of scheduling logics (Frandsen \& Bruun 2007: 12). The producer's choice principle was a way of establishing a competitive market and promoting the competition for programming ideas, while the production workers' employment became short-term and dependent on their ability to generate and sell ideas (ibid.).

Inspired by Ellis and Ytreberg, Henrik Søndergaard has developed four different commissioning models stretching from the order-controlled model where the broadcaster 
orders the production unit to make a specific programme (also described in Ellis 2000: 143 ) to the offer-controlled model where production unit takes the initiative and makes a specific programme and then offers it to the broadcaster. DR3's commissioning practice is most similar to Søndergaard's dialogue-controlled model where the development of programming ideas is negotiated as a part of a collaboration between the broadcaster and the production unit which can involve an encounter between two different creative (sub-)cultures (Søndergaard 2003: $10 \mathrm{ff}$ ).

Critiques of the producer's choice principle are present throughout several research efforts, one example is Georgina Born's study of the BBC: "[T]he need to secure another contract militated against risk-taking or originality and towards the need to flow with prevailing trends" (Born 2005: 186). Søndergaard is also slightly critical towards the short-term contracts and the related uncertainty for workers which he describes as a creative disadvantage, while he at the same time acknowledges the principle's ability to stimulate ideas (Søndergaard 2003: 19). In return, Bruun and Frandsen explain the logics behind involving independent production companies at the Danish channel TV 2 as an opportunity for more hungry players to get involved and that the broadcasters hoped it would result in fewer production expenses (Frandsen \& Bruun 2007: 10f). The principle has also been applied by the highly-lauded production unit DR Drama where it is sometimes used as a part of DR's own explanation of their successful production model (Redvall 2011: 185ff).

In comparison to DR Drama, it can be said that DR3 and their collaborating in-house production unit, DR Ung, do not share many other practical similarities with the DR Drama department or, for example, their use of 15 specific production dogmas (ibid.). Instead of the privileged cultivating of a group of talented employees (scriptwriters, directors, showrunners, etc.) that DR Drama has used, the practice at DR3 with its lower budgets has been to make very broad briefs and wait for either in-house or independent production units to pitch financially viable fiction ideas. This practice, in fact, distributes most of the initiative to the production units. Some of these DR3 briefs had specifically been about satire (and not about fiction in general) and this choice feeds into DR and DR3's track record, which reveals their creative assumptions about making fiction for a younger segment: When they make fiction for a young audience, they always make satire (sketch comedy) and never, for example, drama or other fictional genres.

Historically, DR has a long-running tradition of producing satire series for a younger segment (Bruun 2011) but youth drama (for a 15-29 demographic) has been a somewhat unexplored content area throughout DR's track record where "drama" and "youth fiction" are articulated as two distinctly different genres that are never combined (Andersen \& Sundet 2018). So, in 2013, when DR3 was making their first fictional production, they unsurprisingly adhered to the organisation's logics by commissioning another satire series Kødkataloget [The Meat Catalogue]. ${ }^{3}$

Even Anton 90 was initially pitched and commissioned as another satire series. This happened when New Creations showed DR3 a satiric dummy production where the lead actor playing Anton was a male stand-up comedian in his thirties and the dummy included the use of point-of-view cinematography and a narrative about social media. DR3 liked the cinematography and social media use, but wanted to make the main character younger and after negotiations, the two parties agreed on the production terms (Director, interview, 2017). 
The DR3 channel editors' own perception of DR3 is often characterised by a discourse about being experimental (Head of channel, interview, 2016). This discourse permeates their articulations about the channel and its programmes and has been visible in the promotional texts they use when promoting a new programme. In relation to this self-image, DR3 has generally chosen to commission one-off productions over productions of multiple seasons and this one-off strategy is rather unusual. Their own explanation for their hesitant approach to fiction is primarily based on the assumption about not having enough money, but also that one of their commercial competitors, TV 2 Zulu, has had a strong line-up of original satire/comedy series (ibid.).

In summary, what the producer's choice principle boils down to in DR3's case is the creative assumption that competition and short-term employment is beneficial for the production of television programming. As for the dialogue-controlled model, it implicitly assumes that collaborating and sharing the decision-making process between the two parties is beneficial as well. DR3's briefs mostly imply that a broad and somewhat undefined space for idea generation is more beneficial for idea development. DR3 also demonstrated the creative assumption that yet another satire production was the chosen fiction strategy for reaching a younger audience. Generally, their approach can be summarised with a few words from a DR3 programming editor: "May the best idea win" (Programming editor, interview, 2017). This means that DR3 only accepts the best ideas from the competing production units - but the consequence is also that the potential originality ultimately depends on what the production units pitch to DR3. As noted in Schein's theory (1994: 16f), the members of the organisation take such an assumption for granted without explaining or challenging its status as a naturalised and valid warrant.

\section{New Creations' creative assumptions: The director's agency}

In the case of Anton 90, when I asked my informants about the reasoning behind the decision to make the series in a short format of eight to nine minutes, they gave different answers. Some insisted that it was an artistic and online-minded choice while others explained it as a straightforward budgetary choice due to a lack of funds for a long-form series (Head of channel, interview, 2016). As such, the production had a low budget compared to the local norm in the sense that the scriptwriters only had seven weeks to write 90 minutes of fiction, which meant that they had to draw on material from previous projects. The primary showrunner in this case was not any of the scriptwriters (which is a bit uncommon in television series production) since they were only hired for seven weeks and instead the main creative responsibility fell upon the director (Scriptwriter, interview, 2017).

In Bruun's description of a low-budget social satire production model that was once quite popular at the channel DR2, she explains how they were dependent on a small, multifunctional, creative core of people in order to secure a distinct authorship in the programmes (Bruun 2011: 160f). Anton 90 as a production functioned in a different manner and displayed the creative assumption that delegating the creative authorship to individual freelance employees with each having one specific function would be better in this case. Why New Creations agreed on the relatively meagre production conditions that DR3 offered was defined by my informants as the reality of being a "new and hungry" production company wanting to get a foot in the door - which is similar to the 
aforementioned budgetary logics behind the producer's choice principle described by Bruun and Frandsen (2007). One of the scriptwriters described this reality of meagre working conditions as not very supportive for the quality of the writing, which displays the assumption that quality requires economy and continuity - and in order for him to say yes to an underpaid short-form production again, it would have to be a "con amore project" (Scriptwriter, interview, 2017).

During the preproduction phase, the commissioning DR3 editor who had approved the production of Anton 90 left her position at the channel and was replaced. According to New Creations, the mood of the cooperation changed after this, since the new editor did not seem to have the same sense of ownership of the production (Director, interview, 2017). You might think that New Creations liked this freedom to do what they wanted, but in the end, this shift in editors might have resulted in clashes between different creative assumptions. When the production team began shooting, the series was still meant to be satirical and the script had been written with a comedic show in mind, even though the new DR3 editor had expressed some concerns over the script. According to the director's narrative, the satirical script with its comedic punchlines did not function properly on the set. With only 12 days to shoot the entire series and very little time to memorise lines, a quick decision had to be made. The director could have chosen to use the comedy-heavy script despite its shortcomings on camera but he instead saw the possibility of making a product without the shortcomings by changing the genre in a more dramatic direction. The director eventually made a product that he could vouch for by improvising new and more dramatic lines with the actors and reshooting some scenes (Director, interview, 2017). His audacity to change the genre exposes the assumption that a director's quest for a well-functioning collaboration between cast and script is more important than delivering the exact product that the broadcaster commissioned. That the commissioning editor was not entirely satisfied with this and yearned for the show to have a funnier tone is hardly surprising considering the fact that DR3 did not receive the satire series in which they had invested. The first and preliminary version of the series resulted in diverging opinions between the two parties on the quality, where the DR3 editors asked New Creations for a more layered and experimental aesthetic, more humour and a more realistic narrative (Programme editor, interview, 2017). The director responded to this feedback and arranged for reshoots, but ended up feeling fairly alone in his creative assumptions about how to deliver a well-functioning series - which as Schein notes can be an awkward experience (Schein 1994: 29). In the end, the programme was well received by critics (as mentioned in these reviews: Ludvigsen 2015; Yde 2016) and online viewers. The pilot episode had 200,700 views; the second episode had 96,400 views and the remaining eight episodes had between 45,000 and 75,000 views. ${ }^{4}$ According to the editors, these numbers were satisfying and better than they had anticipated (Programme editor, interview, 2017).

In summary, the risk of failure was present for both parties involved in this collaboration but the short-term freelancers perhaps ran the biggest risk as their future employment was on the line - especially during that period of the process when the editors were unhappy with the product. These freelancers displayed the creative assumptions that quality requires economy and continuity, but their participation in this low-budget production suggests that they - like Taylor and Littleton's art workers - have been motivated by other personal, moral or strategic/career-related needs. In the case of the 
director, he assumed that a well-functioning product was more important than delivering the exact product that the broadcaster commissioned even though a friendly relationship with commissioning editors could be vital to his future employment.

In comparison between the two parties, it can be said that the discourse about this production seemed to change whether the two parties were talking about the difficult process or the positive reception. Somewhere along the way, this production was labelled "a creative success" even though the process was not. That being said, the director's individual agency still came into play and resulted in a product that was deemed original in its context.

\section{Discussion:}

\section{Challenges for studying creativity and agency in media production}

The following discussion will address the findings from the analysis in relation to the article's theoretical perspectives around creativity and media production studies. In relation to Draper's work as well as Lotz and Havens' work presented previously, the analysis here seems to describe a somewhat different sociological phenomenon. According to their claims, media professionals will often select ideas and make decisions that fit with their superior's preferences. Nevertheless, in the case of Anton 90, there appeared to be notable differences in their creative assumptions and taste in the scenario where the parties could not agree on the direction of the production. This might be because none of them had notable experience with producing drama and thus did not know each other's preferences within that genre. In the case of the director, he certainly did not know the DR3 editors' taste and he found it difficult to please them (even though he might have wanted to), which points to Draper's discerned savvy as a mechanism that might be reserved for well-established production cooperations.

In this context, Anna Zoellner's work on the commissioning of independent factual television in Great Britain and Germany (Zoellner 2015) is also of great relevance. As both Born and Zoellner state, the commissioning system in television broadcasting often tends to lead creative workers away from risk-taking and towards previously successful formats and strategies. But in this case example, the freelance director and New Creations did exhibit agency over the production process. They did not merely act as "service providers who need to satisfy their broadcaster clients" (Zoellner 2015: 152), but demonstrated risk-taking independence. Zoellner's book chapter describes "the commercial compliance" and "commercially conformist behaviour" (Ibid: 154), where independent documentary workers' and their creative ideas are powerless against the restrictions applied by broadcasters and their commissioning editors. The findings in this article suggest a difference within this Danish case example, where the power balance between the broadcaster and the independents seems based on a cooperation that both parties mutually agreed on because it can be strategically beneficial for them. ${ }^{5}$

Zoellner and Draper both point to a lack of agency for media workers in the organisations' decision-making process. While that may be true in some cases, it was not what this particular case demonstrated. This contrast illustrates the challenge that arises when we attempt to study creativity in media production: It is often difficult to isolate, identify and define creativity beyond a specific case, as it is a relative term. However, this problem makes showing both sides and choosing cases both for and against the 
issue of agency even more important. The benefit of the social constructivist approach proposed here is that it gives us as researchers the opportunity to minimise normativity, and instead focus on the industry professionals' narrative-discursive constructions of creativity and on the industry's perception of the concept.

\section{Conclusion}

In answer to the research question, the particular case of Anton 90 was an ambivalent mix of consensual collaborations and creative disagreements. Concerning these disagreements, this article has demonstrated how analysing the parties' creative assumptions can provide valuable insights into the minds behind the television industry. DR3's editors approached the cooperation with the creative assumption of "may the best idea win" and, in their self-understanding, they have supported experimental productions that should "go beyond the brief". However, it seems that the freelance director's creative assumptions about taking risks led to a product that was far from the editors' expectations. Perhaps this came as a surprise because it was implicitly expected of him to follow the principle of discerned savvy (Draper 2014) and adhere to the editors' established taste. Instead, these freelance workers articulated the assumptions that quality requires economy and continuity, and that a well-functioning product was more important than delivering the exact product that the broadcaster initially commissioned.

This case shows that there can be a difference between industry professionals' assumptions and actions and between the values of broadcasters and freelance production workers when negotiating discursive assumptions of what creativity and quality require. These editors' and freelancers' feelings about the quality of the production were largely affected and transformed by both positive and negative discourses during the production process. These circumstances pointed to the social negotiation of creativity that surrounded this production through the industry professionals' narratives and discursive evaluations (Taylor \& Littleton 2012) more than they pointed to an inspirationist or romantic force of individual genius. This article proposes that taking the social constructivist approach when trying to analyse creativity in media production studies can aid us in demonstrating the implicit mechanisms that enable the valuation of a product like Anton 90 to change several times before, during and after the production process.

DR3 did not get the satire series that their strategic brief asked for but New Creations also had to deal with the loss of their supportive DR3 editor during the process. Despite these differences and a small budget, it is important to acknowledge the fact that this production process was still completed, that the final product achieved some degree of success and that both parties maintained a professional relationship with one another. This was not simply a case where the creative worker (e.g., the director in this example) was a victim without agency that was alienated from the cultural product - if anything it was the commissioning editors who distanced themselves towards the end of the production process.

Findings suggest that DR3's commissioning strategy, where production is outsourced and separated from distribution, relies heavily on idea generation from production units and encourages short-term, one-off fiction projects that the DR3 editors perceive as more original and consequently a better strategic investment. Despite the relative success of Anton 90, DR3 decided not to make a second season. This choice is grounded in DR3's self-image of being experimental, which might also explain why the production model 
used for Anton 90 was not applied to other fiction productions. The remaining question is whether DR3 will continue to prefer their strategy of making one-off programmes with short-term workers over a strategy of making continuous multi-season projects with a focus on the long-term development of production talents. The latter approach seems to have been used fruitfully by DR Drama for many years (Redvall 2011) and by NRK Super/P3 with SKAM [SHAME] and its showrunner Julie Andem (Andersen \& Sundet 2018).

Anton 90 also demonstrates that a low-budget production is still able to fit the gatekeepers' (critics, audiences, editors) taste and achieve some degree of success. Imitated commercial market logics, cost-effectiveness and overall meagre conditions affected this production greatly and still these conditions did not prevent Anton 90 from being labelled as a somewhat successful and innovative production. In some ways, this points to how the social negotiation of creativity might have a greater influence on the "creative value" of an original fiction series than the actual economic working conditions. Instead of post-rationalising the fates of most television productions by using economic arguments, this article suggests that the actual cost is not always the most important parameter for making successful television, and, above all, highlights the significance of the socially negotiated creative value.

Therefore, the fact that DR3 has been hesitant about making fiction cannot merely be defended with an economic argument saying that their budget has not been large enough, as it seems like money is not the most important condition. Even if DR3's budget had been larger (which is dependent on the higher economic politics within and around DR), DR3's fiction strategy still relies heavily on the idea input from in-house independent production units. It is not this article's intent to say that DR3's cost-cutting approach is misguided, given that they are subjected to strict budgetary restraints from DR Media; but it is fairly easy to conclude that DR3, in the first four years of the channel's life, chose not to prioritise this content area.

Until now, Netflix has yet to compete with the established Danish channels' original Danish-language fiction since their only original Danish-language production, so far, has been a third season of the TV 2 dramedy Rita (TV 2 2012-). However, some winds of change are blowing through DR's organisation, and the youth content department DR Ung has recently created a new production team with a focus on digital content, satire and fiction (Managing editor, interview, 2017) and DR3 has released several new fiction productions in the Autumn of 2017. The new digital production team at DR Ung represents DR's most recent response to the changes in the Danish market brought on by the digitisation of the television medium. This changing market makes it a strategic necessity for this public-service media institution to continuously secure a young target audience, and the fiction content is a highly desired, but also organisationally challenging, commodity. 


\section{Elite informants}

Director, interviewed in January 2017.

Head of channel, interviewed in July 2016.

Managing editor, interviewed in January 2017.

Programme editor, interviewed in February 2017.

Scriptwriter, interviewed in January 2017.

Quotes were translated from Danish to English by the author.

\section{Notes}

1. This article uses Taylor \& Littleton's theoretical approach to creativity but has a different methodological framework. Where Taylor \& Littleton's methodological framework focuses on the art workers' identities and explores the many personal meanings and motivations for pursuing a career in the creative industries, my use of production analysis focuses specifically on the actions and assumptions that occurred within a particular production process.

2. The term "producers" can unfortunately have several meanings: Often it means a programme producer in charge of managing a production team; or a general term for all staff involved with production. But the tasks of a producer can also vary greatly from genre to genre (Tunstall 1993: 2). The producer's choice principle could even be used to describe an organisational shift towards commercialisation and implementing competition and market conditions, which is what I allude to here. The principle of "producer choice" was first introduced at the BBC in the years 1991-94 (Harris \& Wegg-Prosser 1998).

3. DR3 had previously broadcast another fiction series called Kolonien [The Colony] which was also a satire production by DR Ung but initially made for DR HD. As such, it was not originally meant for DR3, but when DR HD closed and DR3 inherited their wavelength, DR3 also inherited the second season of Kolonien.

4. These numbers are DR Media Research's estimates based on the two periods where Anton 90 was available on their VOD catch-up service.

5. One distinction in comparing this work to Zoellner's research on factual programming might be that this case example is a fiction production. But an important detail in this particular setup is that DR3 does not seem to distinguish procedurally between factual and fiction in the pitching and commissioning process: All the independent production companies (both factual and fiction) are included in the same pitching rounds and they are generally given similar procedural treatment.

\section{References}

Andersen, Mads \& Sundet, Vilde Schanke (2017). Digitising youth fiction: A comparative analysis of two Nordic approaches. Forthcoming.

Banks, Mark (2007). The politics of cultural work. Basingstoke: Palgrave Macmillan.

Born, Georgina (2005). Uncertain vision: Birt, Dyke and the reinvention of the BBC. London: Vintage.

Bruun, Hanne (2011). Dansk tv-satire: Underholdning med kant [Danish TV satire: Eentertainment with an edge]. Copenhagen: Books on Demand.

Bruun, Hanne (2014). Eksklusive informanter: Om forskningsinterviewet som redskab i produktionsanalysen [Exclusive informants: About the research interview as a tool in production analysis]. NordicomInformation, 36(1): 29-45.

Caldwell, John Thornton (2008). Production culture: Industrial reflexivity and critical practice in film and television. North Carolina: Duke University Press.

Csikszentmihalyi, Mihaly (1988). Society, culture and person: A systems view of creativity, pp. 325-339 in Sternberg, Robert J. (ed.) The nature of creativity: contemporary psychological perspectives. Cambridge: Cambridge University Press.

Csikszentmihalyi, Mihaly (1991). Commentary. Human Development, 34(1): 32-34 doi:10.1159/000277030

Cunningham, Stuart (2009). Trojan horse or Rorschach blot? Creative industries discourse around the world. International Journal of Cultural Policy, 15(4): 375-386. doi:10.1080/10286630902977501

Draper, Jimmy (2014). Theorizing creative agency through 'discerned savvy': A tool for the critical study of media industries. Media, Culture \& Society, 36(8): 1118-1133.

Ellis, John (2000). Seeing things: television in the age of uncertainty. London: Tauris.

Frandsen, Kirsten (2007). Produktionsanalyse: Teoretiske og metodiske problemstillinger [Production analysis: Theoretical and methodological issues], pp. 23-54 in Frandsen, Kirsten \& Bruun, Hanne (eds.). Tv-produktion - nye vilkår [TV production - new conditions]. Frederiksberg: Samfundslitteratur. 
Frandsen, Kirsten, \& Bruun, Hanne (2007). TV-produktion i konkurrence [TV production in competition], pp. 7-20 in Frandsen, Kirsten \& Bruun, Hanne (eds.). Tv-produktion - nye vilkår [TV production - new conditions]. Frederiksberg: Samfundslitteratur.

Hammersley, Martyn, \& Atkinson, Paul (1995). Ethnography: Principles in practice. London: Routledge.

Harris, Martin \& Wegg-Prosser, Victoria (1998). The BBC and producer choice: A study of public service broadcasting and managerial change. Wide Angle - A Quarterly Journal of Film History, Theory, Criticism, and Practice, 20(2): 150-163.

Havens, Timothy, \& Lotz, Amanda D. (2016). Understanding media industries. Oxford: Oxford University Press.

Heiselberg, Lene, \& Høy Svenningsen, Uffe (2016). Streamingtjenester vinder fortsat terræn [Streaming services continue to gain terrain], pp. 22-29 in Medieudviklingen 2016 [The media development 2016]. Copenhagen: Danmarks Radio.

Hesmondhalgh, David (2013). The cultural industries. London: SAGE.

Knudsen, Henrik Gregor \& Birk, Mette (2016). Flow er stærkest, men streaming mærkes [Flow is strongest, but streaming is felt], pp. 6-11 in Medieudviklingen 2016 [The media development 2016]. Copenhagen: Danmarks Radio.

Kvale, Steinar \& Brinkmann, Svend (2015). Interview: Det kvalitative forskningsinterview som håndvark [Interview: Tthe qualitative research interview as a craft]. Copenhagen: Hans Reitzel.

Laclau, Ernesto \& Mouffe, Chantal (2001). Hegemony and socialist strategy: towards a radical democratic politics. London: Verso.

Ludvigsen, Jacob (2015). Anton 90. Soundvenue.dk, 27 December 2015 [online ]. Available at $<\mathrm{http}$ ://soundvenue.com/film/2015/12/anton-90-177501>. [Accessed 1 May 2017].

Mayer, Vicki; Banks, Miranda J. \& Caldwell, John Thornton (2009). Production studies: cultural studies of media industries. New York: Routledge.

McIntyre, Phillip (2012). Creativity and cultural production: issues for media practice. Basingstoke: Palgrave Macmillan.

Meza, Ed (2017). Netflix invests nearly $\$ 2$ billion in European productions, promises more. Variety.com, 1 March 2017 [online]. Available at <www.variety.com/2017/biz/global/reed-hastings-netflix-berlin100-million-subscribers-1201999745/>. [Accessed 1 May 2017].

Redvall, Eva Novrup (2010). Manuskriptskrivning som kreativ proces: De kreative samarbejder bag manuskriptskrivning $i$ dansk spillefilm [Screenwriting as a creative process: The creative cooperations behind screenwriting in Danish cinema]. Copenhagen: Københavns Universitet.

Redvall, Eva Novrup (2011). Dogmer for tv-drama: Om brugen af one vision, den dobbelte historie og crossover i DR's søndagsdramatik [Dogmas for TV drama: About the use of one vision, the double story and crossover in DR's Sunday dramas]. Kosmorama: Tidsskrift for filmkunst og filmkultur, 248: 180-198.

Runco, Mark A. \& Jaeger, Garrett J. (2012). The standard definition of creativity. Creativity Research Journal, 24(1): 92-96. doi:10.1080/10400419.2012.650092

Schein, Edgar H. (1994). Organisationskultur og ledelse [Organisational culture and leadership]. Copenhagen: Valmuen

Søndergaard, Henrik (2003). Programfladestyring og organisationsforandringer i nordisk public servicefjernsyn [Scheduling strategies and organisational changes in Nordic public service television]. $\mathrm{Me}$ dieKultur, 19(35): 5-22

Taylor, Stephanie (2013). The lived experience of a contemporary creative identification, pp. 175-184 in Chan, Janet \& Thomas, Kerry (eds.). Handbook of research on creativity. Cheltenham: Edward Elgar Publishing Ltd.

Taylor, Stephanie \& Littleton, Karen (2012). Contemporary identities of creativity and creative work. Farnham: Ashgate.

Tunstall, Jeremy (1993). Television producers. London: Routledge.

Westmeyer, Hans (1998). The social construction and psychological assessment of creativity. High Ability Studies, 9(1): 11-21. doi:10.1080/1359813980090102

Yde, Katrine Hornstrup (2016). Veloplagt komedieserie på DR3 viser ungdommen uden for voldene. Politiken. $d k$. 2 January 2016 [online]. Available at <http://politiken.dk/kultur/filmogtv/tvanmeldelser/art5604955/ Veloplagt-komedieserie-p\%C3\%A5-DR3-viser-ungdommen-uden-for-voldene >. [Accessed 1 May 2017].

Ytreberg, Espen (2000). Tekstproduksjonsstudier som medievitenskapelig forskningsområde [Text production studies as a media studies research area]. Nordicom Information, 2: 51-60.

Zoellner, Anna (2015). Detachment, pride, critique: Professional identity in independant factual television production in Great Britain and Germany, pp. 150-163 in Banks, Miranda J.; Conor, Bridget \& Mayer, Vicki (eds.). Production studies, the sequel!: Cultural studies of global media industries. New York: Routledge.

MADS MØLLER ANDERSEN, PhD student, School of Communication and Culture, Aarhus University, mandersen@cc.au.dk 